\title{
Vliv somatických faktorů na výkonnost studentek Fyzioterapie FZS UJEP v Ústí n. L.
}

\section{Influence of physical factors on performance of the students of Physiotherapy at J. E. Purkyně University in Ústí nad Labem, the Faculty of Health Studies}

\author{
Kateěina Vaníková, Zdeněk Havel \\ Fakulta zdravotnických studií, Univerzita J. E. Purkynè v Ústí nad Labem
}

\begin{abstract}
Abstrakt
Cílem studie je přispět k rozšiřrení poznatků o úrovni základní výkonnosti studentek oboru Fyzioterapie FZS UJEP v Ústí nad Labem a jejím ovlivnění somatickými faktory.

Pro účely sdělení jsme formulovali dvě hypotézy, první, základní výkonnost studentek oboru Fyzioterapie vykazuje v prvním roce studia stabilní úroveň, a druhou, úroveň výkonnosti studentek tohoto oboru bude v motorických testech významně ovlivněna somatickými faktory. Studentky absolvovaly tyto testy: progresivní člunkový běh na 20 metrů, Katch-McArdle Step Test, hod plným míčem obouruč 2 kg těžkým, skok daleký z místa odrazem snožmo, výdrž ve shybu na hrazdě - držení podhmatem, leh - sed opakovaně po dobu jedné minuty, hluboký předklon v sedu a lowa Brace test. Dále jsme změřili somatické faktory tj. tělesnou výšku, tělesnou hmotnost, aktivní tělesnou hmotu a tělesný tuk. Aktivní tělesná hmota a tělesný tuk byly zjištovány pomocí prístroje Body jett (rok výroby 2010) a to pouze u souboru studentek měrených v roce 2014.

Z výsledků vyplynulo, že průměrný index BMI patří u obou souborů do skupiny „normální hodnota“. U souboru z roku 2014 vykazovalo 31 \% studentek vyšši hodnoty procent tělesného tuku nežje normální hodnota. Základní výkonnost studentek oboru Fyzioterapie vykazuje v prvním roce studia shodnou úroveň. Výsledky nepotvrdily, že úroveň základní výkonnosti je u studentek ovlivněna somatickými faktory.
\end{abstract}

\section{Abstract}

The study contributes to the knowledge expansion regarding basic level performance of the students studying Physiotherapy in Usti nad Labem, the Faculty of Health Studies. The study shows influence somatic factors on the performance.

For the study purposes two hypotheses are set: the first one is that the basic level performance of the students studying Physiotherapy is indicated as rather stable during the first year of study, and the second one is that the basic level performance of the students studying the same programme is greatly influenced by somatic factors in motoric tests. The students performed the following tests: the $20 \mathrm{~m}$ progressive shuttle run test, Katch-McArdle step test, both hands $2 \mathrm{~kg}$ ball throwing test, standing broad jump test, body strength test with a horizontal bar, lie down-stand up 1 min exercise test, seated forward bend test and lowa Brace test. Additionally, the somatic factors such as body height, body weight, lean body mass and body fat were measured. Active body mass and body fat of the students' tested in the year 2014 were calculated using Body Jett device.

The results show that the average BMI can be considered as normal in both groups. The student group of the year 2014 showed $31 \%$ higher level of body fat than the norm. The basic level performance of the first-year students studying Physiotherapy is stated as stable. The results confirmed that the students' basic level performance is influenced by somatic factors.

Klíčová slova: fyzioterapie, měření a testování, základní tělesná výkonnost, aktivní tělesná hmota a tělesný tuk 


\section{Keywords: physiotherapy, measurement and testing, basic physical fitness, lean body mass and body fat}

\section{Úvod}

V předkládané studii navazujeme na článek Havel \& Vaníková (2013) publikovaný v tomto časopise. $Z$ výsledků studie vyplynulo, že úroveň výkonnosti studentek oboru Fyzioterapie je v motorických testech ve srovnání s obecnou populací shodná a že dosažené hodnoty průměrného indexu BMI, jsou podle norem Riegrové \& Ulbrichové (1993), v souladu s populačním průměrem. Při řešení základní výkonnosti těchto studentek nás zaujaly výsledky v jednotlivých motorických schopnostech natolik, že jsme se rozhodli pro další ověřování tohoto problému.

Pro studium Fyzioterapie i budoucího pracovního uplatnění je nutná základní výkonnost. Lze se domnívat, že pro kvalitní výkon profese fyzioterapeuta je kromě základní výkonnosti důležitá i existencí optimálních somatických faktorů jako je aktivní tělesná hmota, procento tuku apod. Rozhodli jsme se proto znovu ověřit základní výkonnost studentek studijního oboru Fyzioterapie v prvním roce studia a rozširrit naše sdělení o řešení vztahů mezi somatickými faktory a základní výkonností. Naše sdělení se týká kromě BMI také aktivní tělesné hmoty a tukové tkáně.

Aktivní tělesná hmota je charakterizována jako veškerá netuková tkáň. Je nazývána aktivní z toho důvodu, že při své činnosti spotřebovává energii. Mezi aktivní tělesnou hmotu řadíme svaly, kosti, vnitřní orgány, minerály a další složky (Hainer 2001). Tukovou tkáň považujeme za pasivní tělesnou hmotu a označujeme ji „tuk“. Při nadbytečném př́ijmu potravy vzniká nadbytečné množství energie, která se v organismu ukládá ve formě tukových zásob. Tuk, sám o sobě, není pro organismus jen škodlivý, plní řadu důležitých funkcí. Podstatné je, kolik tuku lidské tělo obsahuje. Vyskytuje se ve třech formách, jako bílá tuková tkáň, hnědá tuková tkáň a viscerální tuk. Viscerální neboli „skrytý“ tuk je v dnešní době označován za nejnebezpečnější formu tělesného tuku. Ukládá se mezi vnitřními orgány a obklopuje je. Tento tuk je metabolicky aktivnější než tuk podkožní, nebot uvolňuje do krevního řečiště chemické látky, které mohou vést ke vzniku zdravotních problémů (Riegerová, Přidalová \& Ulbrichová 2006). Shodně jako v článku Havel \& Vaníková (2013) jsme se zaměřili na motorické schopnosti. Byli jsme si vědomi, že motorické schopnosti nejsou př́mo měřitelné (Měkota \& Novosad 2005) a že na jejich úroveñ usuzujeme pomocí indikátorů, což byly v tomto príípadě motorické testy.

Pro naše sdělení jsme si položili dvě otázky. První, jaká je úroveň základní výkonnosti (motorických schopností) studentek Fyzioterapie ve srovnání s obecnou populací a druhou, jak množství aktivní tělesné hmoty a množství tuku ovlivňuje výkonnost v jednotlivých motorických testech.

Cílem studie je přispět k rozšíření poznatků o úrovni základní výkonnosti studentek oboru Fyzioterapie FZS UJEP v Ústí nad Labem a jejím ovlivnění somatickými faktory.

\section{Hypotézy}

1. V prvním roce studia vykazuje základní výkonnost studentek oboru Fyzioterapie shodné hodnoty.

2. Úroveň výkonnosti v motorických testech studentek oboru Fyzioterapie bude významně ovlivněna somatickými faktory.

Pro splnění cíle a hypotéz jsme si stanovili tyto úkoly:

1. Testovat v roce 2014 studentky 1. roku studia studijního oboru Fyzioterapie motorickými testy.

2. Změřit u těchto studentek somatické faktory - BMI, aktivní tělesnou hmotu a tělesný tuk.

3. Srovnat základní výkonnost studentek 1. roku studia v letech 2013 a 2014. Oba soubory srovnat s výkonností obecné populace.

4. Ověřit závislost jednotlivých motorických testů na somatických faktorech. Především nás zajímá, které motorické schopnosti jsou významně ovlivněny somatickými faktory? 


\section{Metodika práce}

Použili jsme stejné testové položky jako v článku Havel \& Vaníková (2013), kde jsou podrobně popsány. Testy byly převzaty z literatury. Základní literaturou byl „Unifittest (6 - 60) Měkota \& Kovář, et al., (1996), měření i testování probíhalo podle manuálu uvedeného v této literatuře. Výjimku činí Katch-McArdle Step Test, z kterého usuzujeme na aerobní zdatnost, je popsán včetně hodnocení v literatuře Pollock \& Wilmore (1990). Druhou výjimkou byl test hodu plným míčem obouruč 2 kg těžkým, jenž je uveden včetně norem v literatuře Komeštíka (2006). Normy pro obecnou populaci jsou uvedeny v tabulkách 1-3.

Tabulka 1 Klasifikace (normy) aerobní kapacity pro ženy 20 - 29 r.

\begin{tabular}{|l|l|l|l|l|l|}
\hline Úroveň & Nízká & Podprůměrná & Průměrná & Nadprůměrná & Vysoká \\
\hline Ženy & $<29$ & $29-34$ & $35-40$ & $41-46$ & $>46$ \\
\hline
\end{tabular}

Převzato: Pollock \& Wilmore (1990)

Tabulka 2 Normy Unifittestu (6-60) žen ve věku 18 - 20 roků

\begin{tabular}{|l|c|c|c|c|}
\hline Hodnocení & Skok daleký & Leh - sed & $\begin{array}{c}\text { Vytrvalostní } \\
\text { člunkový běh }\end{array}$ & Výdrž ve shybu \\
\hline $\begin{array}{l}\text { Výrazně } \\
\text { podprůměrný }\end{array}$ & do -154 & do -26 & do $-3,50$ & 0 \\
\hline Podprůměrný & $155-174$ & $27-33$ & $3,51-5,00$ & $1-5$ \\
\hline Průměrný & $175-194$ & $34-41$ & $5,01-6,75$ & $6-14$ \\
\hline Nadprůměrný & $195-214$ & $42-48$ & $6,76-8,50$ & $15-33$ \\
\hline $\begin{array}{l}\text { Výrazně } \\
\text { nadprůměrný }\end{array}$ & 215 a více & 49 a více & 8,51 a více & 34 a více \\
\hline
\end{tabular}

Převzato: Měkota \& Kováŕ, et al. (1996)

Tabulka 3 Normy pro hodnocení lowa - Brace testu, hlubokého předklonu v sedu a hodu plným míčem 2 kg těžkým

\begin{tabular}{|l|c|c|c|}
\hline Hodnocení & výborně & dobře & špatně \\
\hline IOWA - BRACE test & $>16$ bodů & $13-16$ bodů & $<13$ bodů \\
\hline Hluboký předklon v sedu & $>15 \mathrm{~cm}$ & $15-5 \mathrm{~cm}$ & $<5 \mathrm{~cm}$ \\
\hline Hod plným míčem & $>7 \mathrm{~m}$ & $7-5 \mathrm{~m}$ & $<5 \mathrm{~m}$ \\
\hline
\end{tabular}

Převzato: Komeštík (1995)

Somatické faktory tj. tělesná výška a tělesná hmotnost byly změřeny o obou souborů a byl z nich stanoven index BMI. Aktivní tělesná hmota a tělesný tuk byly zjištovány pomocí př́istroje Body jettu (rok výroby 2010) a to pouze u souboru studentek v roce 2014.

\section{Testové položky a baterie Iowa Brace testu}

1. progresivní člunkový běh na 20 metrů,

2. Katch-McArdle Step Test (Pollock \& Wilmore 1990) - hodnocení dle hodnoty maximální spotřeby kyslíku $\left(\mathrm{VO}_{2} \max \right)$, 
3. hod plným míčem obouruč 2 kg těžkým,

4. skok daleký z místa odrazem snožmo,

5. výdrž ve shybu na hrazdě - držení podhmatem,

6. leh-sed opakovaně po dobu jedné minuty,

7. hluboký předklon v sedu,

8. Iowa Brace test (dále jen IBT).

\section{Charakteristika souboru}

Výzkumné soubory tvořilo 39 studentek prvního roku studia studijního oboru Fyzioterapie měřených v roce 2013 (dále jen soubor 2013) a 32 studentek prvního roku studia studijního oboru Fyzioterapie měřených v roce 2014 (dále jen soubor 2014). Studentky obou souborů prošly prrijímacím řízením na základě teoretických testů z biologie člověka a somatologie. Byly vybrány z celkového počtu 359 (soubor 2012) respektive 316 (soubor 2013) uchazečů ze středních škol. Věk je uváděn $\mathrm{k}$ datu měření s přesností jednoho měsíce (tab. 4). Testování probíhalo $\mathrm{v}$ únoru a březnu roku 2013, v dalším roce pak v březnu v roce 2014 ve sportovní hale PF UJEP. Měření somatických faktorů probíhalo v březnu 2014 na FZS UJEP.

Tabulka 4 Průměrný věk a počty studentek v souborech

\begin{tabular}{|c|c|c|}
\hline \multirow{2}{*}{ Soubor 2013 } & $\overline{\mathrm{x}}$ & 20,9 \\
\cline { 2 - 3 } & $\mathrm{n}$ & 39 \\
\hline \multirow{2}{*}{ Soubor 2014 } & $\overline{\mathrm{x}}$ & 21,1 \\
\cline { 2 - 3 } & $\mathrm{n}$ & 32 \\
\hline
\end{tabular}

\section{Statistické zpracování}

Pro statistické vyhodnocení dat jsme použili program Statistica a provedli následující statistické výpočty: základní statistické charakteristiky polohy a variability (aritmetický průměr, směrodatná odchylka, Me, Mo, $\mathrm{R}$ - variační rozpětí), korelační koeficient $r$, pro věcnou významnost pak koeficient determinace $\mathrm{r}^{2}, \mathrm{t}$ - test pro nezávislé výběry, Mann

Whitney $\mathrm{U}$ test, $\chi 2$-test, pro věcnou významnost pak $\mathrm{d}, \omega^{2}, \eta^{2}$.

\section{Výsledky}

Výsledné hodnoty testových položek, hodnoty Iowa Brace testu (IBT) a somatických faktorů jsou uvedeny v tab. 5 a 6 . Průměrné hodnoty BMI a motorických testů žen obou souborů jsou porovnány $\mathrm{t}$ - testem pro nezávislé výběry $\mathrm{v}$ tab. 7. Hodnoty BMI a IBT jsou srovnávány $\chi^{2}$-testem v tab. 8 a 9. Hodnoty IBT jsou srovnávány Mann Whitney U - testem v tab. 7. Interkorelace somatických faktorů a testových položek studentek souboru 2014 jsou uvedeny v tab. 10.

\section{Složení těla}

Ze somatických faktorů byla měřena tělesná výška a tělesná hmotnost pro výpočet BMI, dále jsme zjištovali aktivní tělesnou hmotu a tělesný tuk. Odvozená hodnota indexu BMI (tab. 5 a 6) nás informuje o tom, zda aktuální tělesná hmotnost odpovídá tělesné výšce nebo zda je nadměrná či snížená. Vypočítaný průměrný index BMI obou souborů patří podle norem Riegrové \& Ulbrichové (1993) do skupiny „normální hodnota“ (tab. 5, 6). V tab. 7 je srovnání $\mathrm{t}$ - testem pro nezávislé výběry, rozdíl je signifikantní při hladině $0,01 \mathrm{v}$ neprospěch souboru 2014. Srovnání skupin BMI $\chi^{2}$ - testem (tab. 8) rovněž potvrdilo rozdíl těchto souborů na hladině významnosti 0,01 v neprospěch souboru 2014. Procento tělesného tuku u souboru 2014 vykazovalo vyšší hodnoty, vysoké procento bylo zjištěno u 10 studentek. 
Tabulka 5 Statistické charakteristiky somatických znaků a testů souboru studentek 2013.

\begin{tabular}{|l|r|r|r|r|c|}
\hline Testy & $\overline{\mathbf{x}}$ & SD & Me & Mo & $\mathbf{R}$ \\
\hline BMI & 21,27 & 2,52 & 20,57 & 19 & 10 \\
\hline Fáze & 4,0 & 1,37 & 4 & 4 & 6 \\
\hline VO $_{2 \max }$ & 43,8 & 4,1 & 43,6 & 48 & 17 \\
\hline Hod & 6,1 & 8,6 & 6,0 & 5,5 & 3,7 \\
\hline Skok daleký & 170,9 & 23,8 & 170 & 160 & 96 \\
\hline Výdrž ve shybu & 27,7 & 17,1 & 27 & 45 & 60 \\
\hline Sed - leh & 31,3 & 4,2 & 32 & 31 & 21 \\
\hline Flexibilita & 27,3 & 8,1 & 26 & 18 & 29 \\
\hline IBT & - & - & 12 & 12 & 16 \\
\hline
\end{tabular}

Tabulka 6 Statistické charakteristiky somatických faktorů a testů souboru studentek 2014.

\begin{tabular}{|l|r|r|r|r|r|}
\hline Testy & $\overline{\mathbf{x}}$ & SD & Me & Mo & \multicolumn{1}{c|}{ R } \\
\hline BMI & 24,3 & 4,0 & 23,4 & 20,5 & 15,6 \\
\hline Fáze & 4,4 & 1,7 & 4,5 & 5,0 & 6,0 \\
\hline VO, max & 42,1 & 3,7 & 42,6 & 44,0 & 13,3 \\
\hline Hod & 6,4 & 1,0 & 6,5 & 5,8 & 4,4 \\
\hline Skok daleký & 164,0 & 20,3 & 164,5 & 183,0 & 84,0 \\
\hline Výdrž ve shybu & 16,7 & 14,7 & 16,3 & 0 & 63 \\
\hline Sed - leh & 28,3 & 9,1 & 30,0 & 30,0 & 40,0 \\
\hline Flexibilita & 23,5 & 5,6 & 24,3 & 26,0 & 21,0 \\
\hline IBT & - & - & 11 & 11 & 13 \\
\hline \% Svalové hmoty & 65,6 & 5,2 & 65,6 & 71,1 & 20,1 \\
\hline \% Tuku & 25,2 & 5,6 & 25,3 & 22,7 & 21,5 \\
\hline
\end{tabular}

Tabulka 7 Srovnání hodnot BMI a testů souborů studentek 2013 a 2014.

\begin{tabular}{|l|c|c|c|}
\hline Testy & $\mathbf{t}$ - test & effect size d, $\omega^{2}$ & $\%$ \\
\hline BMI & $3,76 * *$ & 0,168 & 16,8 \\
\hline Fáze & 1,15 & - & - \\
\hline VO $_{2 \max }$ & 1,35 & - & - \\
\hline Hod & 1,01 & - & - \\
\hline Skok daleký & 1,41 & - & - \\
\hline Výdrž ve shybu & $2,42 *$ & 0,070 & 7,0 \\
\hline Sed - leh & 1,54 & - & - \\
\hline Flexibilita & $2,78^{* *}$ & 0,094 & 9,4 \\
\hline IBT & p-level $=0,00429 *$ & 0,2486 & malý efekt \\
\hline
\end{tabular}

hladina významnosti t - testu *) $\left.\mathrm{t}_{0,05}=1,99 * *\right) \mathrm{t}_{0,01}=2,65$

Tabulka 8 Srovnání BMI podle norem Riegrová, J. \& Ulbrichová, M. (1993) u souborů 2013 a 2014.

\begin{tabular}{|c|c|c|c|c|c|c|}
\hline Soubory/index & podváhu & $\begin{array}{c}\text { normální } \\
\text { hodnota }\end{array}$ & nadváha & $\begin{array}{c}\text { mírná } \\
\text { obezita }\end{array}$ & \multirow{2}{*}{$\boldsymbol{\eta}^{2}$-test } & $\begin{array}{c}\text { effect size } \\
\boldsymbol{\eta}^{2} \mathbf{v} \%\end{array}$ \\
\hline Soubor 2013 & 16 & 21 & 2 & 0 & \multirow{2}{*}{12,998} & \multirow{2}{*}{6,10} \\
\hline Soubor 2014 & 3 & 21 & 4 & 4 & & \\
\hline
\end{tabular}

hladina významnosti $\chi_{0,01}^{2}=11,34$ 
Tabulka 9 Srovnání IOWA - BRACE testu podle norem Komeštíka (1995) u souborů 2013 a 2014.

\begin{tabular}{|c|c|c|c|c|}
\hline Soubory & Špatně & Dobře & Výborně & $\chi^{2}$-test \\
\hline Soubor 2013 & 22 & 11 & 6 & \multirow{2}{*}{3,112} \\
\hline Soubor 2014 & 22 & 9 & 1 & \\
\hline
\end{tabular}

hladina významnosti $\chi_{0,05}^{2}=5,99$

Tabulka 10 Korelace somatických faktorů a testů souboru 2014.

\begin{tabular}{|l|l|c|c|}
\hline Znak & BMI & \% Aktivní tělesná hmota & \% Tuku \\
\hline Flexibilita & 0,102 & $-0,152$ & 0,146 \\
\hline Dálka & $-0,446 *$ & $0,512 * *$ & $-0,512 * *$ \\
\hline Leh-sed & $-0,044$ & 0,226 & $-0,226$ \\
\hline Výdrž & $-0,386 *$ & $0,430 *$ & $-0,431 *$ \\
\hline Hod & 0,085 & $-0,097$ & 0,098 \\
\hline Fáze & $-0,519 * *$ & $0,670 * *$ & $-0,670 * *$ \\
\hline VO2 & $-0,124$ & 0,212 & $-0,208$ \\
\hline IBT & $-0,366 *$ & 0,344 & $-0,344$ \\
\hline BMI & - & $-0,904 * *$ & $0,903 * *$ \\
\hline
\end{tabular}

hladina významnosti *) $\left.\mathrm{r}_{0,05}=0,349 \quad * *\right) \mathrm{r}_{0,01}=0,449$

\section{Motorické testy}

Srovnáme-li průměrné hodnoty jednotlivých testů studentek obou souborů s normami pro obecnou populaci uvedenými v literatuře „Unifittest (6 - 60) Měkota \& Kovář, et al., (1996), (tab. 2), zjištujeme, že se u některých testových položek jedná o poměrně nižší výkonnost. Podprůměrných hodnot dosáhly tyto studentky v progresivním člunkovém běhu na 20 metrů - fáze, v testu skok daleký z místa odrazem snožmo a v lehu - sedu opakovaně po dobu jedné minuty. Nadprůměrné byly ve své věkové kategorii v testu výdrže ve shybu na hrazdě a v hlubokém předklonu $v$ sedu. Rovněž nadprůměrné byly v aerobní zdatnosti - Katch-McArdle Step Testu podle norem Pollocka \& Wilmora (1990) v tab. 1. Podle norem Komeštíka (2006) je výsledný průměr v hodu plným míčem obouruč $2 \mathrm{~kg}$ těžkým v průměru jejich věkové kategorie (tab. 3 ).

Srovnáním hodnot testů u obou souborů jsme zjistili, že se výsledky liší jen minimálně. Statisticky vyšších hodnot dosáhly studentky měřené v roce 2013 (tab. 7) a to v testu výdrž ve shybu na hrazdě, na hladině významnosti 0,05 , v hlubokém předklonu v sedu, na hladině významnosti 0,01 a v IBT, kde došlo podle Cohenova koeficientu o věcné významnosti k malému efektu. Minimální rozdíl potvrzuje srovnání tohoto testu podle norem Komeštíka (1995) $\chi^{2}$-testem, nebot' nejde o statistickou významnost (tab. 9).

\section{IBT}

V tab. 5 a 6 jsou výsledné hodnoty IBT testu v rámci hodnocené baterie, medián, modus a variační rozpětí. Mediány i modusy se liší pouze o jeden bod, variační rozpětí má vyšší soubor studentek 2013. Hodnoty IBT jsou porovnány Mann Whitney U testem (tab. 7), zjistili jsme statistickou významnost mezi soubory ve prospěch souboru studentek 2013 na hladině významnosti $\alpha_{0,05}$, jde však o věcnou významnost s malým efektem. Z norem Komeštíka (2006) a výpočtu $\chi^{2-}$ 
-testu můžeme potvrdit, podle počtu studentek, shodnou výkonnost ve skupinách obou souborů (tab. 9).

Korelace testů a somatických faktorů

Výpočtem korelací motorických testů a somatických faktorů jsme chtěli zjistit, jaké jsou vzájemné vztahy mezi somatickými faktory a skupinami motorických schopností u souboru studentek 2014. V tab. 10 jsou uvedeny statistické významnosti. Statistickou závislost jsme zjistili u skupiny motorických schopností vytrvalostních, ve výdrži ve shybu a progresivním člunkovém běhu na 20 metrů a to kladnou, s aktivní tělesnou hmotou a zápornou s tělesným tukem. Zápornou korelaci jsme rovněž vypočítali u IBT a BMI. U explozivně silové schopnosti jsme vypočítali korelaci pouze u skoku dalekého z místa odrazem snožmo, na hladině významnosti $0,01 \mathrm{~s}$ aktivní tělesnou hmotou a zápornou s tělesným tukem, na hladině 0,05 . Dále jsme zjistili zápornou korelaci BMI se skokem dalekým z místa. Oproti předpokladu jsme již další statistickou významnost nezaznamenali.

\section{Diskuse}

Jak uvádíme v úvodu, srovnáváme opakovaně úroveň výkonnosti studentek studijního oboru Fyzioterapie $\mathrm{v}$ prvním roce studia $\mathrm{v}$ motorických testech (základní výkonnost) a rozšiřujeme naše sdělení o řešení vztahů mezi somatickými faktory a základní výkonností.

Výkonnost studentek studijního oboru Fyzioterapie srovnáváme s obecnou populací a opakovaně v prvním roce studia.

Jsme přesvědčeni, že by studentky Fyzioterapie měly mít dobrou základní výkonnost, nebợ jejich budoucí profese vyžaduje v souvislosti s charakterem pracovní zátěže i vysokou kvalitu svalové koordinace a určitou úroveň zdatnosti.

\section{BMI}

Vypočítaný průměrný index BMI patři podle norem Riegerové, J., Přidalové, M. \& Ulbrichové, M. (2006) u obou souborů do skupiny „normální hodnota“ (tab. 5 a 6). Podíváme-li se však na jednotlivé probandky v souborech, zjištujeme, že u studentek souboru 2013 mělo podváhu 16 studentek a pouze dvě nadváhu, u souboru 2014 měly pouze 3 studentky podváhu, 4 nadváhu a 4 mírnou obezitu. V tab. 7 a 8 je srovnání obou souborů. Přestože se potvrdil rozdíl těchto souborů na hladině významnosti 0,01 v neprospěch souboru 2014, oba soubory se průměrem řadí do normální hodnoty. Vyšší hodnoty souboru 2014 přisuzujeme objemu svalové hmoty, což BMI nebere v úvahu. Můžeme přesto konstatovat, že složení těla studentek z obou souborů je v souladu s populačním průměrem a výsledné hodnoty nás vedou $\mathrm{k}$ přesvědčení, že studentky vysoké školy kontrolují svoji hmotnost.

Odborníci na somatotypy a výživu se neshodují na normální hodnotě tuku. Obecně se přijímá množství v rozmezi $18-28 \%$.

U souboru 2014 jsme u 10 studentek zjistili více než $28 \%$ tuku. Domníváme se, že je nutné množství tuku u těchto studentek snízit. Náš názor je posilován i zjištěnou maximální hodnotou 36,3 a variačním rozpětím souboru (tab. 6). Vypočítali jsme korelaci BMI a aktivní tělesné hmoty i tuku, oba korelační koeficienty jsou shodně vysoké $(\mathrm{r}=0,903)$, jedná se o hladinu významnosti 0,01 .

\section{Motorické testy}

1. Výsledky potvrdily naší 1 . hypotézu, že v prvním roce studia vykazuje základní výkonnost studentek oboru Fyzioterapie shodné hodnoty.

Studentky měly shodné výsledky ve všech testech kromě výdrže ve shybu na hrazdě držení podhmatem a v hlubokém předklonu v sedu - flexibilitě. Vyšší hodnoty testové položky výdrž ve shybu přisuzujeme nižší hmotnosti studentek z roku 2013. U flexibility hrají významnou roli genetické 
předpoklady, ty se u souboru 2013 projevily i u baterie IBT. Výsledné hodnoty motorických testů nám daly odpověd’ na naší první otázku, jaká je úroveň základní výkonnosti studentek Fyzioterapie ve srovnání s obecnou populací. Studentky sice dosáhly podprůměrných hodnot ve vytrvalostních testech, ale $\mathrm{v}$ dalších byly nadprůměrné nebo $\mathrm{v}$ průměru obecné populace. Znamená to, že proti očekávání studentky vysoké školy nepřevyšují obecnou populaci v základní výkonnosti.

Výsledky nepotvrdily naši 2 . hypotézu, že úroveň výkonnosti v motorických testech studentek oboru Fyzioterapie jako celku bude významně ovlivněna somatickými faktory a zároveň nám daly odpověd' na druhou otázku, jak množství aktivní tělesné hmoty a množství tuku ovlivňuje výkonnost $\mathrm{v}$ jednotlivých motorických testech - schopnostech (tab. 10).

Z vypočítaných korelací vyšla očekávaná závislost vytrvalostních testů (progresivním člunkovým během na 20 metrů, výdrži ve shybu na hrazdě) a to kladná s aktivní tělesnou hmotou a záporná s tělesným tukem. Rovněž jsme očekávali závislost mezi somatickými faktory a $\mathrm{VO}_{2}$ max, která se však neprojevila. Záporná korelace IBT s BMI, která je statisticky významná, se rovněž dala předpokládat, podobně jako kladná s aktivní tělesnou hmotou a záporná s tělesným tukem, kde se vypočítané hodnoty „r“ přibližují kritické hodnotě. U explozivně silové schopnosti jsme vypočítali korelaci pouze u skoku dalekého z místa odrazem snožmo, a proto nás překvapily nízké hodnoty u hodu plným míčem obouruč 2 kg těžkým, nebot jde o shodnou motorickou schopnost. Více korelací jsme u souboru nezjistili.

Z korelačních koeficientů i vlastního testování lze konstatovat, že výkonnost v jednotlivých testech, kromě somatických faktorů, závisí i na provádění či neprovádění pohybových aktivit, spíše však na získávání pohybových dovedností. Přičemž pohybové dovednosti se aktivně podílí na celé ontogenezi, utváří a usměrňují vývoj organismu člověka. Racionální zařazování pohybu do denního režimu je nezbytné, stejně jako jeho analýza (Zvonař, M. et al., 2011).

\section{IBT}

Testová baterie IBT obsahuje koordinačně náročné pohyby, rovnovážné a koordinační tělesná cvičení, některé položky je možno pokládat i za test flexibility. V tab. 5 a 6 jsou výsledné hodnoty IBT medián, modus a variační rozpětí, v tab. 9 je pak uvedeno splnění normy Komeštíka (2006) jednotlivými probandy. Měkota \& Novosad (2005) uvádí, že maximální výkonnost v koordinačních schopnostech je v období 20 - 30 let věku. $Z$ výsledků vyplývá, že $56 \%$, respektive 68 studentek Fyzioterapie test nesplnilo a my můžeme znovu usuzovat na nízký rozvoj koordinačních schopností $\mathrm{v}$ rámci školní tělesné výchovy $\mathrm{v}$ předcházejícím studiu.

Výsledky testů motorických schopností a z nich vyplývající základní výkonnost změnily náš názor, že tyto studentky budou provádět ve volném čase pohybovou aktivitu a budou dosahovat v motorických testech vyšších hodnot. Tento názor byl podpořen poznatkem Zvonaře, $M$. et al. (2011), že právě období adolescence je pokládáno za vrchol motorické aktivity života člověka, kdy mizí anatomické disproporce a diskoordinace motoriky předchozího období.

\section{Závěr}

1. Pro odpověd’ na naše otázky, hypotézy a úkoly jsme nashromáždili hodnoty 39 studentek prvního roku studia v roce 2013 a 32 studentek prvního roku studia v roce 2014 studijního oboru Fyzioterapie FZS UJEP v Ústí nad Labem.

2. Studentky jsme změřili v těchto testech: progresivní člunkový běh na 20 metrů, Katch-McArdle Step Test, hod plným míčem obouruč 2 kg těžkým, skok daleký z místa odrazem snožmo, výdrž ve shybu na hrazdě - držení podhmatem, leh - sed opakovaně po dobu jedné minuty, hluboký předklon v sedu a Iowa Brace test. Dále jsme změřili somatické faktory tj. tělesnou výšku a tělesnou hmotnost, z nichž byl stanoven index BMI, aktivní tělesnou hmotu a tělesný tuk. 


\section{Z výsledků vyplynulo:}

a) Vypočitaný průměrný index BMI patří podle norem Riegrové \& Ulbrichové (1993) u obou souborů do skupiny „normální hodnota“. U souboru 2014 jsme naměřili u 31 \% studentek vyšší hodnoty tělesného tuku než je normální hodnota.

b) Výsledky potvrdily naší 1 . hypotézu, že v prvním roce studia vykazuje základní výkonnost studentek oboru Fyzioterapie shodné hodnoty. Studentky obou souborů měly shodné výsledky ve všech testech kromě výdrže ve shybu na hrazdě a v hlubokém předklonu v sedu - flexibilitě.

c) Výsledky nepotvrdily naši 2 . hypotézu, že úroveň výkonnosti v motorických testech studentek oboru Fyzioterapie bude významně ovlivněna somatickými faktory. $Z$ vypočitaných korelačních koeficientů lze vyvodit závěr, že tomu tak není.

d) Ukázalo se však, že aktivní tělesná hmota ovlivňuje pozitivně vytrvalostní schopnosti (progresivní člunkový běh na 20 metrů, výdrž ve shybu na hrazdě) a explozivně silovou schopnost (skok daleký z místa odrazem snožmo). Na druhé straně se potvrdilo, že množství tělesného tuku tyto schopnosti ovlivňuje negativně. Rovněž se potvrdilo, že vyšší hodnoty BMI negativně ovlivňují dovednosti testové baterie IBT.

\section{Literatura}

Bunc, V. (1998). Zdravotně orientovaná zdatnost a možnosti její kultivace na základní škole. Těl. Vých. Sport. Mlád. č. 4, 2 -10. Čelikovský, S. et al. (1990). Antropomotorika pro studující tělesnou výchovu. (3. prèprac. vyd.) Praha: Státní pedagogické nakladatelství.

Čepička, L. (1999). Stanovení obtížnosti motorického testu. Česká kinantropologie. 3(1). 87-94.

Hainer, V. (2001). Obezita. Praha:Triton.

Jurca, R. et al. (2005). Assessing Cardiorespiratory Fitness Without Performing Exercise Testing. American Journal of Preventive Medicine, vol. 29, no. 3. 185-193.

Komeštík, B. (2006). Kinantropologie - Antropomotorika - Metodologie. (1. vyd.) Olomouc: Univerzita Palackého.

Máček, M., \& Radvanský, J. (2011). Fyziologie a klinické aspekty pohybové aktivity. Praha: Galén.

Měkota, K., Kovář, R. et al. (1996). Unifittest (6 - 60). Manuál pro hodnocení základní motorické výkonnosti a vybraných charakteristik tělesné stavby mládeže a dospělých v České republice. Ostrava: Pedagogická fakulta Ostravské univerzity.

Měkota, K. \& Novosad, J. (2005). Motorické schopnosti. Olomouc: Univerzita Palackého v Olomouci, Fakulta tělesné kultury.

Ministerstvo zdravotnictví České republiky (2011). Vyhláška č. 55 o činnostech zdravotnických pracovníků a jiných odborných pracovníkü. Praha: Ministerstvo vnitra, p.o.

Pollock, M. L. \& Wilmore, J. (1990). Exercise in health and disease: Evaluation and prescription for prevention and rehabilitation. Philladeplhia:W. B. Saunders.

Riegrová, J. \& Ulbrichová, M. (1993). Aplikace fyzické antropologie v tělesné výchově a sportu. Olomouc: Univerzity Palackého v Olomouci, PF.

Riegerová, J., Přidalová, M. \& Ulbrichová, M. (2006) Aplikace fyzické antropologie v tělesné výchově a sportu (příručka funkční antropologie). 3. vyd. Olomouc: Hanex.

Štěpnička, J. (1976). Somatotyp, držení těla, motorika a pohybová aktivita mládeže. Praha: Univerzita Karlova, FTVS.

Zvonař, M., Pavlík, J., Vespalec, T. \& Duvač, I. (2011). Antropomotorika: pro magisterský program tělesná výchova a sport. (1. vyd.) Brno: Masarykova univerzita. 